\title{
Erratum to: the link between adjacent codon pairs and mRNA stability
}

Yuriko Harigaya* and Roy Parker

\section{Erratum}

After publication of this article [1], the authors noticed two errors:

In Table $3 \mathrm{~B}$ and $\mathrm{D}$, the column labels should be "Frame 0", "Frame 1", and "Frame 2" rather than "Frame 0", "Frame 0", and "Frame 0." (Table 3).

A corrected version of Table 3 is included with this Erratum.

In the "Calculation of partial correlation coefficients" section in Methods, the expression of the Pearson's covariance matrix is incorrect. The denominator should be $n-1$ instead of $n$. In the corrected version, the authors clarify the computational implementation used. Also, the authors now follow the convention where random variables are expressed in uppercase letters.

A corrected version of this follows below (references included in the revised portion are referring to the original article):

\section{Methods}

\section{Calculation of partial correlation coefficients}

To examine associations of the content of inhibitory codon pairs with various gene expression variables controlling for covariates, we first attempted to use multiple linear regression models with exclusion of outliers and logarithmic transformation of skewed variables. However, we found that the models failed to satisfy the assumption of residual homogeneity (see below). We therefore chose to use non-parametric methods throughout the study.

We computed Spearman's and Kendall's partial correlation coefficients as described previously [16]. Briefly, we let $\mathrm{X}$ be a $\mathrm{p}$-dimensional random vector $\left(\mathrm{X}=\left[\mathrm{X}_{1} \mathrm{X}_{2}\right.\right.$ $\left.\cdots X_{p}\right]^{T}$ ) and $c_{i j}$ be the covariance between two random variables $X_{i}$ and $X_{j}(1 \leq i, j \leq p)$. We denote the covariance matrix of $X$ as $C_{X}$, the inverse covariance matrix as $D_{X}$, and the $(i, j)$ element of $D_{X}$ as $d_{i j}$. We then let $X_{S}$ be a vector that contains all elements of $X$ except $X_{i}$ and $X_{j}$.
The partial correlation of $X_{i}$ and $X_{j}$ given the vector $\mathrm{X}_{\mathrm{S}}$ is

$$
r_{i j \mid S}=-\frac{d_{i j}}{\sqrt{d_{i i}} \sqrt{d_{j j}}}
$$

The Spearman's and Kendall's covariance matrices were constructed as implemented in the $\operatorname{cov}()$ function in the $\mathrm{R}$ base package [43].

We computed $P$ values by previously described methods as implemented in the pcor() function in the $R$ ppcor package [16] as well as by permutation tests. To obtain permutation $P$ values, we randomly permuted the predictor variables and computed correlation coefficients. We repeated the procedure for 10,000 times and computed a permutation $P$ value as $(\mathrm{B}+1) /(\mathrm{N}+1)$, where $\mathrm{N}$ is the number of permutations. $\mathrm{B}$ represents the number of events where the permutation correlation coefficient exceeds the empirically observed value.

Received: 25 August 2017 Accepted: 25 August 2017

Published online: 08 September 2017

\footnotetext{
Reference

1. Harigaya $Y$, Parker R. The link between adjacent codon pairs and mRNA stability. BMC Genomics. 2017;18:364. DOl:10.1186/s12864-017-3749-8.
}

* Correspondence: yuriko.harigaya@colorado.edu

Department of Chemistry and Biochemistry, Howard Hughes Medical

Institute, University of Colorado Boulder, Boulder, CO 80303, USA (c) The Author(s). 2017 Open Access This article is distributed under the terms of the Creative Commons Attribution 4.0 International License (http://creativecommons.org/licenses/by/4.0/), which permits unrestricted use, distribution, and reproduction in any medium, provided you give appropriate credit to the original author(s) and the source, provide a link to the Creative Commons license, and indicate if changes were made. The Creative Commons Public Domain Dedication waiver (http://creativecommons.org/publicdomain/zero/1.0/) applies to the data made available in this article, unless otherwise stated. 
Table 3 Test for associations of the out-of-frame inhibitory codon pairs with mRNA decay rate, protein per mRNA, and ribosome occupancy

(A) Spearman's partial correlation based on the fraction of the inhibitory codon pairs

\begin{tabular}{|c|c|c|c|c|c|c|c|c|c|}
\hline & & Frame 0 & & & Frame 1 & & & Frame & \\
\hline & $\rho$ & $P$ value & Perm. & $\rho$ & $P$ value & Perm. & $\rho$ & $P$ value & Perm. \\
\hline & & & $P$ value & & & $P$ value & & & $P$ value \\
\hline mRNA decay rate (Cramer 1$)$ & 0.14 & $2.1 \mathrm{E}-18$ & 1.0E-04 & 0.05 & $1.0 \mathrm{E}-03$ & 7.0E-04 & 0.02 & 3.4E-01 & 1.7E-01 \\
\hline mRNA decay rate (Cramer 2) & 0.15 & $1.2 \mathrm{E}-20$ & $1.0 \mathrm{E}-04$ & 0.02 & $2.4 \mathrm{E}-01$ & $1.3 \mathrm{E}-01$ & 0.03 & 3.8E-02 & $1.8 \mathrm{E}-02$ \\
\hline mRNA decay rate (Gresham) & 0.07 & $9.0 \mathrm{E}-06$ & $1.0 \mathrm{E}-04$ & 0.06 & $2.0 \mathrm{E}-04$ & 2.0E-04 & 0.01 & $5.2 \mathrm{E}-01$ & $6 \mathrm{E}-01$ \\
\hline mRNA decay rate (Coller) & 0.06 & $2.0 \mathrm{E}-04$ & $1.0 \mathrm{E}-04$ & 0.02 & $2.2 \mathrm{E}-01$ & $1.1 \mathrm{E}-01$ & 0.03 & 4.6E-02 & $2.4 \mathrm{E}-02$ \\
\hline Protein per mRNA & -0.07 & 4.9E-05 & 1.0E-04 & 0.03 & 8.6E-02 & 4.3E-02 & 0.01 & 7.2E-01 & $6 \mathrm{E}-01$ \\
\hline Ribosome occupancy & -0.06 & $8.8 \mathrm{E}-05$ & 1.0E-04 & 0.02 & $2.0 \mathrm{E}-01$ & $9.9 \mathrm{E}-02$ & 0.01 & $5.2 \mathrm{E}-01$ & 2.7E-0 \\
\hline
\end{tabular}

(B) Kendall's partial correlation based on the fraction of the inhibitory codon pairs

Frame $0 \quad$ Frame 1

\begin{tabular}{|c|c|c|c|c|c|c|c|c|c|}
\hline & $\tau$ & $P$ value & $\begin{array}{l}\text { Perm. } \\
P \text { value }\end{array}$ & $\tau$ & $P$ value & $\begin{array}{l}\text { Perm. } \\
P \text { value }\end{array}$ & $\tau$ & $P$ value & $\begin{array}{l}\text { Perm. } \\
P \text { value }\end{array}$ \\
\hline mRNA decay rate (Cramer 1$)$ & 0.15 & $2.4 \mathrm{E}-48$ & $1.0 \mathrm{E}-04$ & 0.04 & $6.7 \mathrm{E}-04$ & $1.0 \mathrm{E}-04$ & 0.00 & 7.7E-01 & $3.8 \mathrm{E}-01$ \\
\hline mRNA decay rate (Cramer 2) & 0.16 & $9.8 \mathrm{E}-49$ & $1.0 \mathrm{E}-04$ & 0.02 & $2.5 \mathrm{E}-02$ & 9.7E-03 & 0.02 & 7.1E-02 & $3.2 \mathrm{E}-02$ \\
\hline mRNA decay rate (Gresham) & 0.10 & $7.9 \mathrm{E}-22$ & $1.0 \mathrm{E}-04$ & 0.08 & $2.6 \mathrm{E}-13$ & $1.0 \mathrm{E}-04$ & 0.03 & $1.3 \mathrm{E}-02$ & 4.0E-03 \\
\hline mRNA decay rate (Coller) & 0.07 & $6.2 \mathrm{E}-10$ & $1.0 \mathrm{E}-04$ & 0.01 & $6.1 \mathrm{E}-01$ & 3.1E-01 & 0.01 & $3.8 \mathrm{E}-01$ & $2.0 \mathrm{E}-01$ \\
\hline Protein per mRNA & -0.11 & $7.3 \mathrm{E}-20$ & $1.0 \mathrm{E}-04$ & 0.01 & 3.7E-01 & 1.7E-01 & 0.01 & $6.2 \mathrm{E}-01$ & $3.1 \mathrm{E}-01$ \\
\hline Ribosome occupancy & -0.11 & $1.3 \mathrm{E}-30$ & $1.0 \mathrm{E}-04$ & -0.02 & $2.2 \mathrm{E}-02$ & $3.9 \mathrm{E}-03$ & -0.01 & 4.6E-01 & $2.0 \mathrm{E}-01$ \\
\hline
\end{tabular}

(C) Spearman's partial correlation based on the presence/absence of the inhibitory codon pairs

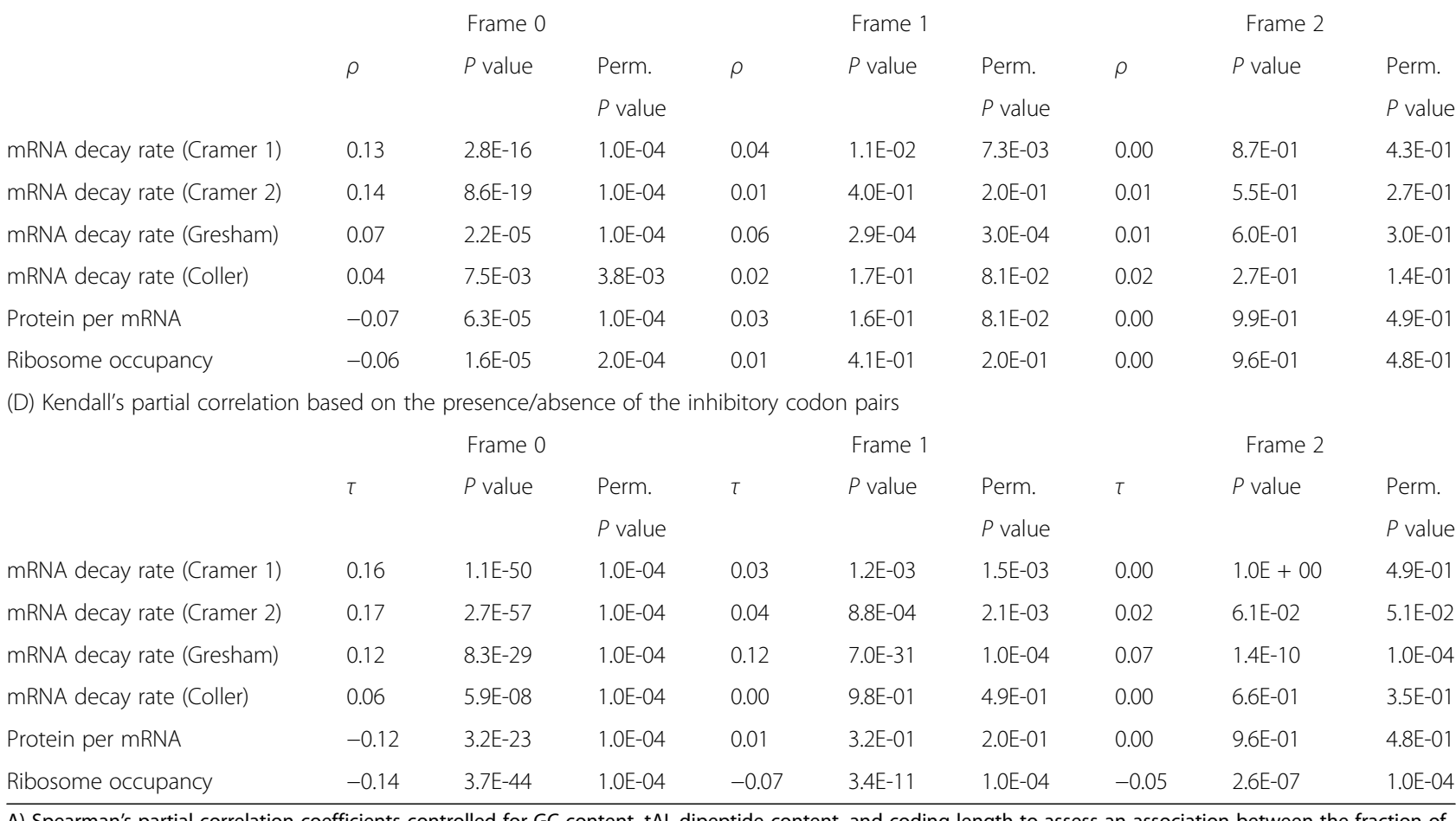

A) Spearman's partial correlation coefficients controlled for GC content, tAl, dipeptide content, and coding length to assess an association between the fraction of hexanucleotide sequences corresponding to the inhibitory codon pairs in the $0,+1$, and +2 frames and various gene expression variables. $P$ values obtained according to Kim [16] and those based on permutation tests are shown. (B) Same as (A) but for Kendall's partial correlation coefficients. (C) Same as (A) but for the presence/absence of the hexanucleotide sequences. (D) Same as (B) but for the presence/absence of the hexanucleotide sequences 